\title{
IDENTITY AND CULTURAL MEMORY IN CVIT \\ RAZGOVORA NARODA I \\ JEZIKA ILIRIČKOGA ALITI \\ RVACKOGA [THE FLOWER \\ OF CONVERSATION OF \\ ILLYRIAN OR CROATIAN \\ PEOPLE AND LANGUAGE] \\ (1747) BY FILIP GRABOVAC
}

Original scientific paper

Submitted: 2. 7. 2019.

Accepted: 11. 10. 2109

DOI: $10.15176 /$ vol56no208

UDK 821.163.42.09Grabovac, F.

\section{GORANKA ŠUTALO}

Croatian Department, Faculty of Humanities and Social Sciences, University of Zagreb

JOSIPA TOMAŠıć

Croatian Department, Faculty of Humanities and Social Sciences, University of Zagreb

This article deals with the textual construction of identity and the strategy of remembrance in Cvit razgovora naroda i jezika iliričkoga aliti rvackoga [The Flower of Conversation of Illyrian or Croatian people and language] (1747) by Filip Grabovac. Using the imagological analytical apparatus, the phenomenon of constituting confessional (Catholic) identity and (dominant Eastern Orthodox) alterity is discussed. The analysis focuses on textual construction or representation of confessional identities, or alterities, wherein numerous value-charged expressions are present. Given the importance of the sociohistorical context in imagological research, the paper takes into account not only the history of literature, but also the history of culture. In addition to imagological treatment, Grabovac's text is also examined within the framework of cultural memory; discursive strategies of remembrance which maintain the constructed identity are analysed, firm reference points of memory and symbolic figures to which memory adheres are identified.

Keywords: Filip Grabovac, Cvit razgovora [The Flower of Conversation], identity/alterity, cultural memory, imagological analysis 


\section{IDENTITY AND CULTURAL MEMORY}

The concept of identity in the postmodern age is understood as a (discursive) construct which becomes a very complex analytic category. Therefore, in social sciences and humanities identity becomes a central term or "an idea which cannot be thought in the old way, but without which certain key questions cannot be thought at all" (Hall 1996: 2). There are two aspects of identity - personal and collective - they are interrelated because "asking 'who you are' makes sense to you only once you believe that you can be someone other than you are" (Bauman 2004: 19). At the basis of all postmodernist deliberations is the Other as a reflection in which we recognize ourselves (or our collectivity). According to Ernest Laclau objective 1 identity is but "an articulated set of elements" (Laclau 1990: 32), and not a homogenous point. All identities are therefore "dislocated" (ibid.: 39); they "are 'dislocated' - that is, experienced as partially incomplete because they can be formed only through differentiation that simultaneously limits the identity by making it dependent on the presence of an 'Other'” (Martin 2005: 100). Alterity is therefore understood as a constitutive and complementary notion in relation to the notion of identity, and is defined by its opposition and inferiority to identity (Hall 1996).

Postmodern concepts of identity which stress its heterogeneous and constituted nature closely connect identity with memory which, much like identity, is not observed as a given, but rather incorporates concrete efforts in its constitution and maintenance. Identities are maintained through memory, and simultaneously "what is remembered is defined by the assumed identity" (Gillis 1994: 3). Plurality of identities implies plurality of memory with which these identities are shaped and the frameworks within which they are realised. Memory is, therefore, not only studied from the point of view of biographic memory of an individual, but as collective memory (M. Halbwach). ${ }^{2}$ Collective memory as conceived by Jan Assmann is realised in the form of communicative and cultural memory. Assmann defines communicative memory as a memory of a group which refers to the recent past, it is generational (it encompasses three generations), diffuse and functions within the framework of biographic memory. Cultural memory is highly institutionalised, directed toward the absolute past, subsumes specialized carriers and firm foothold in the past, ceremoniality and rituality (J. Assmann 2005: 57-65; 2006: 61-67; 2008). Aleida Assmann explains the dynamics and structure of cultural memory realised in the dialectics of memory and forgetfulness via their two aspects which she terms functional and storage

${ }^{1}$ For details on contingency of objectivity (identity) and constitutive nature of antagonism see: Laclau 1990: $26-27$.

2 Theses about social conditioning of memory and the notion of collective memory (mémoire collective) were developed by French sociologist Maurice Halbwach in the 1920s. German Egyptologist Jan Assman, relying on Halbwach and expanding his theory of collective memory, came up with a theoretical concept of cultural memory. More on M. Halbwach's role in the development of theory of cultural memory see: Marcel and Mucchielli 2008; J. Assmann 2005: 41-52; 2006: 51-61. 
memory, whereby functional memory subsumes forms which secure repetition, while storage memory implies forms which secure duration ${ }^{3}$ (A. Assmann 2011: 63-68).

On the other hand, Pierre Nora ${ }^{4}$ approaches memory in opposition to remembrance history recognizing the discontinuity which led to the feeling of the "division of memory". Nora is interested in strategies of representation of the past and formulates the notion of sites of memory (lieux de mémoire) which function as an anchor to the memory of new societies (Nora 2006: 28-29). They are produced by different discursive practices, and are thus deeply ideological (see: den Boer 2008: 21).

In Steven Knapp's model, collective memory is observed from the viewpoint of the narration which supports it and which undoubtedly participates in the construction of identity. Not every narration has normative status, and Knap refers to narration which does have normative power as authoritative history, the carrier of "collective authority" (2006: 81). Memory is always selective and (re)constructed, and, like identity, according to Gillis (1994: 3), is a subjective phenomenon.

Considering Filip Grabovac's Cvit razgovora [The Flower of Conversation] (1747) from the point of view of the theories of identity and cultural memory provides opportunities for new insights into this text of the Dalmatian Franciscan priest. The destiny of Grabovac's text (the work was banned, all available copies were confiscated and publicly burned, while the author was accused of anti-Venetian activity and imprisoned in the infamous Sotto $i$ piombi prison) testifies to the fact that memory of selected events, which form constitutive elements of the construction of community identity, is also a strategy of resistance to official, "imposed" historical narrations.

Through the application of the imagological ${ }^{5}$ method, which focuses on issues of identity/alterity, the article addresses the phenomenon of the constitution of confessional (Catholic) identity and (predominantly Eastern Orthodox) alterity. Grabovac's text is also examined within the framework of cultural memory, where parts of Cvit razgovora are

${ }^{3}$ Aleida Assman compares the relation between functional and storage memory to the canon - archives relation. Canonisation procedures, as one of the key mechanisms of functional cultural memory, retain cultural artefacts in the active memory of a society revitalizing them through new readings, interpretations, stagings, evaluations. The canon therefore represents active memory which the past "preserves as presence" while, on the other hand, the archive represents a paradigmatic institution of passive cultural memory where "the past is preserved as the past" (see: A. Assmann 2008).

${ }^{4}$ In his influential study on sites of memory (lieux de mémoire), published in the first volume of the Les Lieux de mémoire 1984 edition, historian Pierre Nora, the editor of this edition, problematizes the relation between memory and history pointing to the loss of continuity, a break with the past which occurred in modern societies. As a result of the loss of natural environment of memory the so-called sites of memory (lieux de mémoire) are created. They are realised in three aspects - material, symbolic and functional - which always coexist (Nora 2006: 36). For history of the concept, the relation between Cicero's and Quintilian's term loci memoriae and Nora's lieux de mémoire, as well for applications of Nora's concept see: den Boer 2008.

${ }^{5}$ Imagology is a research branch of comparative literature (introduced in the study of literature in the 1960s) which studies literary images of foreign (hetero-image) and one's own (auto-image) geo-cultural spaces. Although its main research interest is directed toward ethnic/national images, its approach can be applied to the research of confessional images, as well. See: Leerssen and Beller 2007. 
analysed as reference points in which memory is anchored, moreover symbolic figures to which memory adheres are identified, and memory discursive strategies which have cohesive power and which participate in the construction of communal identity are analysed. Research interest is thus directed toward the textual construction or representation of confessional identities or alterities, wherein numerous value-charged expressions can be detected. Two dimensions, or two meanings of the term identity are important for imagology - the older, diachronic one which subsumes the point of duration and continuity in time (and is basically an auto-image), and a somewhat more recent, synchronic one, which subsumes separate and autonomous individuality and is focused on the difference "Us (Me) / "Others", that is the analysis of hetero-images (Leerssen 2007: 340). Since imagological analysis cannot disregard the importance of the social context (historical contextualisation), in addition to literary and historical knowledge, research has to be based on cultural and historical knowledge as well. This article attempts to define confessional alterity more clearly on the above-mentioned basis, it attempts to show the importance of memory in the constitution of the community and its survival since the assumed (Catholic) identity is constituted precisely through memory and in relation to the Other.

\section{CONFESSIONAL IDENTITY/ALTERITY AND THE CONSTRUCTION OF MEMORY IN GRABOVAC'S CVIT RAZGOVORA [THE FLOWER OF CONVERSATION] (1747) ${ }^{6}$}

In Opomena k štiocu [Reminder to the reader] Grabovac, in his characteristic manner, addresses the reader calling him a brother and provides information important for the understanding of his motive for writing. The first piece of information we get refers to the content of the book "about ancient or past things"7 (Grabovac 1951: 21)), which is followed by an explanation of the motivation for writing about this particular topic ("from whom I have heard more than once, saw people desiring to know and ask, how the past times are to be remembered"8 [ibid.]). With this sentence Grabovac justifies his reason for writing and expresses the interest of his intended audience for the topic of the work. The writing of folk writers is characterised by the respect for the intended audience, the vision of an intended recipient with the awareness of their abilities of reception of a certain content and aesthetic conditioning (see Tomašić 2015).

As an additional argument for writing about the topic Grabovac takes the experience of the languages of other peoples: "I have seen books about this topic in languages other

\footnotetext{
${ }^{6}$ For biographical data on Grabovac and his Cvit razgovora see: Eterović 1927; Matić 1951; Grbavac 1986; Botica 1990; Strukan 1998. All citations in the articles are from the volume edited by Tomo Matić for Stari pisci hrvatski edition, volume 30, Zagreb: JAZU, 1951.

7 "od stvari davni aliti prošasti".

8 "od koji sam mnoge više puta čuo, vidio željne znat i pitat, u komu se načinu uzdržavaju vrimena prošasta”.
} 
than Illyrian or Croatian [...]" (ibid.). ${ }^{9}$ The following specific piece of information mediated by Grabovac refers to the two-part structure of the work; he says that it consists of two parts: "two parts here tied together" (ibid.), ${ }^{10}$ relating to religious discussions (part one) and relating to "representation of centuries, peoples and kingdoms"11 (ibid.) (part two) which is predominantly secular. As with other folk writers, the category of truth gets one of the central positions in Grabovac's work. Insisting on the truth is a poetic determinant of folk literature ${ }^{12}$ (see Tomašić 2016: 138-139), and Grabovac employs it as a powerful argument. By evoking the authority of the truth, by appealing to the veracity of the content expressed in the book, he dismisses all the possible accusations for falsely and/or unfaithfully expressing events: "should other books make claims contrary to our argument, remember that I found a whole lot more of them, but I only used the truthful ones"13 (ibid.). As opposed to Franciscan priest Kačić Miošić, Grabovac does not invoke the sources from which he extracted information, which does not exclude concern for the truth value of the information given. Aware of the possible objections towards the unreliability of his sources because of insufficient substantiation with written evidence, at the very end of Cvit razgovora, in a short dialogue between Mladić [The Young Man] and Starac [The Elder], in the literary manner of the topos of ineffability, he replies to the potential critics:

The Young Man:

I have, grandpa, read your books, but wonder why you never mentioned old raconteurs to testify to your arguments.

The Elder:

[...] This is my reply to you: if I had recorded every raconteur here, and interpreted every book that I desired, the book, my son, could not be carried by a horse, let alone you, tucked into your belt. Nothing less, if you desire to, use the arguments; if not leave them, I am not forcing you to do anything. If you wish to trust them you can just as you trust others; if not, you go ahead and look for yourself.14

\footnotetext{
9 "ja vidjevši knjiga od ovizi stvari ù jezik svaki izvan iliričkoga, aliti rvaskoga [...]”.

10 "ù dva dila ovde zajedno svezana".

11 "ukazanja vikova, naroda i kraljestva".

12 Pučka književnost (folk literature) is a Croatian term used to describe the literary phenomenon which occupies the inter-space between oral and written (artistic) literature. The designation pučki (folk) denotes literature with specific poetic mechanisms which form a unique literary phenomenon (similar examples in the English literature are broadside ballads, chapbooks etc.)

13 "ako bi ù drugim knjigam protivno naša govorenje, spomeni se, da sam ji i jà naša i više, ali sam se služio istinitim".

14 "Mladić:

Ja sam, dide, proštio tvoje knjige, ali se čudim, gdi nisi spomenuo nigdi stari izkazaoca zà svidočbu tvoga govorenja.

Starac:

[...] S prilikom ti odgovaram: da ja budem svakog izkazaoca ovdi zabiližio i svake knjige iztomačio, koje sam štio, ne bi ti ji sinko moglo ni paripče nošiti, a kamo li ti zà pasom. Ništa manje, ako su ti ù volju, služi se; ako li nisu, à ti ji ostavi, ja te nè usilujem. Ako ćeš jim virovati, moreš kao drugim; ako li ne ćeš, a ti pođi traži" (Grabovac 1951: 275).
} 
Grabovac takes the position of authority which secures him the trust of the community which acknowledged him as a specialised bearer of the community's memory.

Grabovac bases the main difference in identity on confessional affiliation which means that "affiliation to one and the same religious community (which is superlocal and imagined)" is interpreted as one of the "pre-national cultural concepts of belonging" (Gulin 1998: 130). According to Joanna Rapacka, the main idea expressed in Grabovac's Cvit razgovora, as well as in Kačić's Razgovor ugodni [A Pleasant Conversation] $(1756,1759)$, "is an apologia for 'what is ours' contrasted with what is foreign", while "the borders of what is ours or the immediate world are identical [...] - Dalmatia, the Venetian border" (Rapacka 1995: 124). Grabovac establishes a contrast between his own space and foreign space i.e. the characters of the enemies - in relation to the Catholic ecumene they are infidels: Saracens, Turks, schismatics (ibid.: 126).

Confessional inclusivity and negative evaluation of the members of confessions other than the Catholic one are visible already in the first part of Cvit razgovora, in a short prose paragraph titled Od dostojanstva Kraljestva Nebeskoga Sveti Augustin [From the dignity of the Kingdom of Heaven Saint Augustine] (Grabovac 1951: 90). As the confessional Other, the following peoples are mentioned: Turks, Jews, infidels, dissenters from the holy faith (ibid.), semi-fidels, Lutherans, Calvinists "and other dissenters from the holy faith and law of Jesus who in their present life got themselves outside the holy Roman Church, Catholic and Apostolic"15 (ibid.). Christian communities outside the Catholic Church most likely belong to the last group which Grabovac considers heretics. After this initial list, Grabovac refers to the predominantly Eastern Orthodox ${ }^{16}$ Christians who cannot be saved outside

15 “i ostali odpadnici svete vire i zakona Isukrstova koji sadašnji život dospiju izvan svete crkve rimske, katoličanske i apostolske".

${ }^{16}$ Eastern Orthodox Christians who arrived to the Venetian Republic at the beginning of the War of Candia (1645-1669), and who form an organised unit already in the 18th century, did not manage to obtain religious autonomy. The root of those failures, according to Mile Bogović, lies in the Republic's fear of increased foreign influence in Dalmatia, and the Catholic hierarchy which was led by two archbishops of Zadar - Vicko Zmajević (1713-1745) and Mate Karaman (1745-1771) at the time (Bogović 1982: 53). Catholic hierarchy in Dalmatia attempted to subordinate Eastern Orthodox Christians to Catholic bishops in their dioceses, and the Eastern Orthodox episcope had no jurisdiction over the territory of the western Patriarchate to which Dalmatia belonged, as well (ibid.: 165). In Venetian Dalmatia, in the 17th and 18th century, there lived Eastern Orthodox Greeks and Morlachs of the Byzantine rite (ibid.: 81) who had been subject to the Patriarchate of Peć prior to the arrival to the territory of the Venetian Republic. The Patriarch, and the regent did not wish to relinquish their jurisdiction over the Morlachs, not even after their decision to leave for another state (ibid.). Eastern Orthodox Christians in Dalmatia thus did not manage to get a separate episcope during the Venetian rule. The reason for this was the Venetian ragion di stato, or the primacy of the state, because of which all Eastern Orthodox episcopes were removed from Dalmatia, under the aegis of the protection of the state. The episcopes mentioned above were foreigners who did not receive approval of the Senate for their activities (ibid.: 166). 
"the holy mother, Church of Rome" (ibid). For such people, "neither christening, or fasting, or collection even if a lot of money is collected, or death in the name of Jesus can be of benefit for the salvation of [their] soul, when it is followed by this schism, rebellion, falling outside Catholic faith and perversity [...]"17 (ibid.). The nomenclature used by Grabovac to refer to Eastern Orthodox Christians is multifarious - they are rebels, schismatics or, derogatory, semi-fidels. ${ }^{18}$ This nomenclature is expanded with two additional terms - Greeks and rišćani, or rkaći ${ }^{19}$ which makes it clear that Grabovac differentiates between Eastern Orthodox Greeks and Eastern Orthodox Slavs. However, in the mentioned paragraph a difference in evaluation between the two terms is not evident. Quite the contrary, both Eastern Orthodox Greeks and rišćani are evaluated as renegades and semi-fidels, while rkaći are, in addition to the above also "a branch fallen off the tree"20 (ibid.). Grabovac clarifies the term starovjerci, ${ }^{21}$ which the Eastern Orthodox appropriate, and which is incorrect because it actually refers to Jews (which he refers to as čifuti, i.e. yids), while he refers to rišćani in more neutral terms this time, as starokalendarci. ${ }^{22}$ In addition to Eastern Orthodox Christians, Grabovac criticizes evil Catholics (ibid.) and warns them not to hope for salvation.

Although the presented terminology offers reason to claim that Grabovac differentiates between Eastern Orthodox Christians (Slavs and Greeks), the above-mentioned chapter reveals that he does not insist on distinguishing them because he uses the term imprecisely and almost synonymously. Therefore, the term Greek as it is used there is closer to Friar Karlo Jurišić's interpretation, who says that Grabovac does not use the older legal term Greek-Eastern, or the more recent one Eastern Orthodox to refer to the members of the Eastern churches, instead referring to them as rišćani or rkaći, or simply Greeks "after the main historical nation which is the bearer of Eastern Orthodoxy" (Jurišić 1983: 220).

The author bases/builds community identity on the awareness of confessional difference, that is, on belonging to the Catholic ecumene. From the imagined community of true believers he excludes all who do not accept the authority of the Roman Catholic Church and denies them the possibility of salvation: "every man who does not uphold the unity and community of the holy mother Roman Church, Catholic and Apostolic [...] or death in the name of Jesus cannot save his soul"; "One who does not uphold the Holy

\footnotetext{
17 "ni krštenje, ni post, ni lemozina, ako će i velika biti, ni smrt zà ime Isukrstovo primljena korist mu ne more biti zà spasenje duše njegove, kad u njemu ova šizma, odmetnutje, polovirnost i opačina slidi [...]".

${ }^{18}$ Members of Christian churches other than Roman Catholic.

${ }^{19}$ In English roughly 'ristians or Greek Christians. The Croatian term rkać or hrkać is a derogatory term used by Dalmatian and Bosnian Catholics for Eastern Orthodox Christians. See Rječnik hrvatskoga ili srpskoga jezika. Vol. XIV, edited by D. Grdenić, J. Hamm et al., Zagreb, JAZU, 1955, 54. Friar Karlo Jurišić states that Grabovac uses the term regularly because he is not aware of the term Eastern Orthodox. The term itself, according to Jurišić, has an unclear origin - some believe that it comes from the word Greek (Greek-Eastern Christians), while others think that it comes from the verb to snore (Croatian: hrkati), or singing through the nose (Jurišić 1983: 219).

20 "odpala grana od svoga cabla".

${ }^{21}$ Literally "followers of the old ritual".

${ }^{22}$ Literally "followers of the old calendar".
} 
Roman Catholic and Apostolic Church for his mother, does not hold God for his father"23 (Grabovac 1951: 90).

Grabovac constitutes a community of memory through discursive procedures of inclusion and exclusion by excluding from the imagined community all opponents of Christianity first, and then opponents of Catholicism, thus strengthening the coherence of the we-community which becomes the bearer of memory and identity: "that not only all the Turks, yids, infidels, all the dissenters from the holy faith, semi-fidels, seducers, Lutherans, Calvinists and other dissenters from the holy faith and law of Jesus [...]"24 (ibid.: 90). Thus he firstly excludes all the heretics from the Christian community ("maraudery or heresy" of John Calvin, Martin Luther (ibid.: 189), Arian "heresy" (ibid.: 249) and Nestorian (ibid.: 252)). ${ }^{25}$ Then from a narrower Catholic community he excludes dishonest Catholics and Catholics of weak faith: "not everyone baptised in the Catholic Church, as I have said, will not have life eternal but only those who shall obey the command of baptism and live justly [...]"; "Not even evil, vicious and unjust shall get to the truth and come to the kingdom of Heaven" (ibid.: 90). ${ }^{26}$ For Grabovac, the identity of the Christian (Catholic) community functions as a surrogate of the national community, and he constitutes it by invoking certain events from the past. Each such invocation implies a selective approach, and Grabovac thus makes a conscious selection of events choosing only those which carry the power of identity. In the context of folk literature to which Grabovac belongs as well, this means that the selection of events "is preceded by the selection of a community which conditions those events" (Dabo Hunjak 2018: 326), which means that the assumed identity defines memory.

The events he selected belong to the religious, as well as secular history. In the first part of Cvit razgovora Grabovac primarily addresses Catholics, predominantly deals with religious themes and provides answers to the questions of the origin of the world and Judgement Day. In the spirit of Christian teaching and admonition, he also includes prayers (for example Molitva svagdanja [The everyday prayer] and Molitva, u verše sastavljena, od pet rana Isukrstovi [Prayer in verses about five wounds of Jesus] (Grabovac 1951: 47), Molitva svetome Mijovilu arkandelu [Prayer to Saint Michael the Archangel]

23 "svaki čovik, koji jedinstvo i skupštine ne drži svete majke crkve rimske, katoličanske i apoštolske [...], ni smrt zà ime Isukrstovo primljena korist mu ne more biti zà spasenje duše njegove," "Crkvu svetu rimsku, katoličansku i apoštolsku tko ne drži zà svoju majku, ne drži ni Boga zà svoga oca.".

24 "da ne samo svi kolici Turci, Čifuti, nevirnici, mali jošter svi kolici odmetnici svete vire, polovirnici, zaodnici, luterani, kalvini i ostali odpadnici svete vire i zakona Isukrstova [...]”.

25 “dušmanluk aliti erežija” (ibid.: 189), "erežije” arijanska (ibid.: 249) i neštorijanska (ibid.: 252).

26 "ni svi, koji su ù crkvi katoličanskoj kršteni, i kako reko, da ni oni ne će svi primiti život vičnji, nego oni, koji će zapovid krštenja obsluživati i pravedno živiti [...]”; "Do istine, tako ne će ni katolici zli, opaki i nepravedni posidovanja imati ù kraljestvu nebeskome” (ibid.: 90). 
(ibid.: 50), Verši od nedilje [Sunday verses] (ibid.: 67)), debates between the body and the soul (for example Od osuđenja jedne siromašne duše [On the condemnation of a poor soul] (ibid.: 53), Tužba duše osuđene, koju čini protiv tilu svome i svim udi tilesni - plače, viče i govori [Lamentation of a condemned soul which transgressed against the body and all the limbs - it cries, screams and speaks] (ibid.: 62), Razdiljenje duše dobre [od] tila pokornoga [Good souls separated from the obedient body] (ibid.: 92)), misogynist "lessons" about the female nature (Od žene, kakve su naravi i kako se od nji valja uklonjati $i$ bižati di mu drago biti [On women, what their nature is and on how you need to stay away from them and run as far as you can] (ibid:: 90)), on raising children (Način za uzdizati malu dicu [Method for raising little children] (ibid.: 159)), on friendship (Od prijateljstva [On friendship] (ibid.: 31)) and on the relationship toward monks (Način općit s redovnici [Manner of communication with the monks] (ibid.: 33)) etc., as well as folk poems which, with their implausible content, dynamics of the plot and terrible events function as a moral on proper Christian activities, the punishment of evil and the omnipresent mercy of God (for example Od Pile [On Pile] (ibid.: 97), Od jednoga strašnog događaja ${ }^{27}$ [On a terrible event] (ibid.: 145)). These poems, as well as the selected historical events function as points of community memory, because their truth value is verified in real life, in the story of what can happen. Such stories about terrible events successfully communicate the desired message, and with their ease of transmission of the message they secure the remembrance of the desired "truths". 28

An important reference point in the choice of events is the Holy Writ. Grabovac invokes the authority of the Holy Writ and the Gospel as the unquestionable truth, and the events he describes he simply lists and analyses primarily from the Christian and Catholic perspective. In the first part, in the versified discussion between The Young Man and The Elder, Grabovac interprets the present and the past, recognizing "harbingers" to which the reference point is the Bible. The author choses certain biblical events based on harbingers he recognises in the present, and the chosen points from the Bible are thus consolidated in the memory of the Christian (Catholic) community: "You are waiting for the stone to start crying / but do not look for harbingers." (ibid.: 25); "What from the design of the world you pick, / you desire to understand better. / Numerous harbingers are to be seen, / but we shall not see that happen. / The greater Script shall be fulfilled, / this, they say, shall not last." (ibid.: 41). ${ }^{29}$ By the selection of the events, and by referring to the Bible as a canonical text, Grabovac additionally consolidates Catholic identity of the we-community.

27 The poem was analysed by Divna Zečević within the framework of the folk literature phenomenon. Zečević interprets the described event (incest) as an example of deviation from the conceived order, and the folk poet as always acting as the defender of this imagined value order, the proper order of things (Zečević 1978: 408, 411-413).

${ }^{28}$ Emina Dabo (2018: 659), drawing on Paul Connerton, sees folk texts (poems) as collective texts, she recognizes their ritual character and their identity potential for the community.

29 “Čekaš plakat ti kamenja, / a ne gledaš sad zlamenja” (ibid.: 25); "Što l' od svrhe svita veliš, / razumiti bolje želiš. / Zlamenja se vide mnoga, / mal ne ćemo vidit toga. / Izpuni se Pismo veće, / to durati vele ne će" (ibid.: 41). 
In the first part Grabovac inserted an overview of the history of the Schism of the Church titled Slidi kratko zabiliženje od vrimena razdiljenja Crkve Iztočnje od Zapadnje [What follows is a short note on the time of the schism between the Eastern and the Western Church] (ibid.: 141-142). In it he mentions the main points of difference between the Eastern and the Western Church - he begins with the Acacian schism (484-519) which stopped as a result of efforts of Pope Hormisdas (514-523) and Emperor Justinian I, he dwells on the Photian schism (863), yet he leaves out the Great Schism of the Church in 1054 which occurred at the time of Patriarch Michael Cerularius. Instead, Grabovac discusses the unification of the two churches - at the Second Council of Lyon in 1274, and especially the Council of Florence (Basel-Ferrara-Florence-Rome, 1431-1445) where the East-West union was signed in 1439. With his negative value attributes given to the Eastern Orthodox Other Grabovac legitimizes the Catholic identity of the we-community.

Patriarch Acacius, excommunicated by Pope Felix III for supporting Henoticon, the imperial and papal edict (Jurišić 1983: 204), is referred to by Grabovac as the "enemy of the Holy Catholic Church"30 (Grabovac 1951: 141). Photius ${ }^{31}$ is also given a series of negative attributes - he is the main reason why the Eastern Church "broke away" ${ }^{2}$ from the Western, he is "damned patriarch Photius" (ibid.), ${ }^{33}$ vicious schismatic and Arian who has, together with "infidel and vicious Caesar Michael" (ibid.) ${ }^{34}$ persecuted Patriarch Ignatius and now unjustly occupies the seat of the patriarch. Grabovac compares the joint action of the Ceasar and Photius with the Turks in derogatory terms - "[...] it was a force so strong as when the Turks are being Turks" (ibid.). ${ }^{35}$ Grabovac calls out Mark, the Archbishop of Ephesus, as well ("a cursed schismatic", ibid.: 142), ${ }^{36}$ "infidel and vicious schismatic or Arian" (ibid.) ${ }^{37}$ as a result of whose actions most Greek bishops decided to revoke the Florentine union.

At the end of the overview Grabovac reflects on the Greeks after the Schism to demonstrate that the superior position of power, as a universal church, belongs only to the Roman Catholic Church:

Before they broke away from the holy church many of the Greeks were virtuous, learned, wise, holy, famous, loud people, heroes, great men and possibly other things, as well. However, after the break away from the holy Roman Catholic and Apostolic Church,

30 "dušmanin s. crkve katoličanske".

31 Photius I (Greek: Фúrıs Phōtios), (c. 820 - between 891 and 898), was the Ecumenical Patriarch of Constantinople from 858 to 867 and from 877 to 886 . He was one of the most influential and most educated patriarchs of Constantinople. He is recognized in Eastern Orthodox Church as Saint Photius the Great (see Šutalo 2015: 192-193).

\footnotetext{
32 "otpala".

33 "prokleti Focijo patrijarka".

34 "nevirnim i opakim Mijajlom cesarom".

35 "tu bi sila, kakono od Turčina da se turče".

36 "prokleti šizmatik".

37 "nevirna i opaka šižmatika aliti arijana".
} 
all of the above attributes vanished, rotted and withered away, there are no more such qualities. They can now only be ridiculed by the world and nations. (ibid.) $)^{38}$

This is when Grabovac uses inter-confessional comparison with the Jews (čifuti) since the Greeks have lost their kingdom and are still waiting for the Caesar, just like the Jews who are still waiting for the Messiah. The main reason why the Greeks have lost their kingdom, Grabovac claims, is Greek infidelity ${ }^{39}$ and arrogance ${ }^{40}$ (ibid.). This Greek infidelity and arrogance are in a causal relationship with the Turkish occupation, which is evident in the gnomic sounding expression - "Greek infidelity, Turkish force, devil's temptation - God let not any of them in!"41 (ibid.) which Grabovac most likely heard among the Catholic populace.

The overview of the Great Schism is followed by a poem in octosyllabic couplets devoted to Eastern Orthodox Christians titled Od naravi, ćudi, običaja i prignutja poloviraca aliti starokalendaraca [On nature, temper, customs and accomplishments of the semi-fidels and old calendar Christians] (ibid.: 142-144). This poem by Grabovac, since it ascribes a series of negative attributes to the Eastern Orthodox people, can be taken as a paradigmatic example of amassing value attributes which reveal the worldview of the author thus generating the image of the Other. In the title of the poem Grabovac uses two terms for Eastern Orthodox Christians, "semi-fidels" and "old calendar Christians". Grabovac reflected on these two terms on an earlier occasion, in a prose paragraph titled Od dostojanstva Kraljestva Nebeskoga Sveti Augustin [On the dignity of the Kingdom of Heaven - Saint Augustine] where he stressed that both terms should be linked to rišćani or rkaći, meaning, Eastern Orthodox (Slavs) in Dalmatia. ${ }^{42}$ Numerous examples in the poem are close to the immediate lived experience and contact with the Eastern Orthodox Christians and reveal that Grabovac was hard on Eastern Orthodox Christians in Dalmatia, and not only Orthodox Greeks as the main culprits for the Great Schism. Thus, for example, already at the beginning, he mentions that he never saw a devout semi-fidel ("I have never seen a devout one", ibid.: 142), ${ }^{43}$ and even when they do adhere to certain laws, they are still evil by nature: "in them neighs evil character" (ibid.). ${ }^{44}$ Furthermore, he claims the following about the Eastern Orthodox Christians:

\footnotetext{
38 "Grci dok od crkve s. ne odpadoše, od nji biše ljudi mnogo kriposni, naučni, mudri, sveti, slavni, glasni, junaci, ljudi velici, mogući i ostala. Mà pokle se razdiliše i odpadoše od s. crkve rimske katoličanske i apostolske, od tada sva rečena izčaznuše, iztrunuše i okopniše, tog nejma drugo više. Ostaše zà balek svita i naroda".

39 "grčka nevirnost".

40 "oholost".

41 "Nevira grčka, sila turska, vražja napast - Bože, ne daj upast!".

42 In the second part of the book, in a short paragraph titled Od promina i vladanja kralja $u$ Taliji [On the changes and governance of the king in Italy] (Grabovac 1951: 193), Grabovac states that Rkaći are actually the descendants of Vandals. Grabovac also found schismatics or rkaći also in Czechia (Bohemia) and in Bulgaria (ibid.: 200).

43 "ja ne vidi njeg devota".

44 "od nji narav na zlo rže".
} 
He talks sweet / but his actions are vicious. / They make a lot of noise, / but nothing comes out of it. They are wild, / they turn others to evil. / Whoever comes into contact with them / sometimes spends the night in jail; They have such laws as they do, / because they are wild? He holds wild things, / he does not care for honesty; They betray, steal holy traditions, / they growl at the old Romans.; They do not have a word of learning / they only want a part of the nights' game.; They do know how to cross themselves - / they should go and graze. (ibid.: 142-144) ${ }^{45}$

Grabovac criticizes thefts which he links to Eastern Orthodox Christians, and writes very ironically about their religious customs, especially their fasting:

They brim with evil, / villainy is in their hands.; Was Sodom worse in anything? / Do not go far, stay at home. / Their lawmakers / are like bag carriers; / learning has no say there, / it serves only to be chucked in the bag. / The only thing they learn is: fast well, / however, you sad people, this is not enough. / When they steal something, when they sin, / they want half of the stolen wealth, so open their wallet.; they attract all kinds of things, / they deserve a harsh punishment. (ibid.: 143-144) ${ }^{46}$

The poem also carries very negatively value-charged expressions which Grabovac uses to depict the characters of Eastern Orthodox Christians, which could be summarized as deceptive and evil:

I have never heard of them doing good deeds, / they do not kneel before God. / When they seem good to you, / it is their heart lying.; They are unfaithful, full of deception, / shall bring evil onto others. / They swear on all kinds of things, / and live the wrong way. They swear full of evil words: / cross yourself, do not have anything to do with them! (ibid.: 143) ${ }^{47}$

In inter-confessional comparisons Grabovac links Eastern Orthodox Christians with Turks and Jews - "Turks are wild / hardened as Jews"48 (ibid.: 143). Sometimes, in comparison with the Turks, Eastern Orthodox Christians are to be found even worse than Turks - " They have nothing but the fast / and Turks at least have Ramadan"49 (ibid.: 144). Grabovac does not forgo the opportunity to call out Eastern Orthodox Christians for their disposition toward the Ottomans, instead of toward the Pope, stressing that he heard them say the

45 "On s jezikom lipo zlati / pak s opaki dili plati. / Od nji čujem mnogo buka, / a ne vidi kog nauka. / Puni jesu divijači, / na zlo drugog sve navlači. / Koji godi š njima obći / u galiji kadgod noći.; Zakonoše kakve jesu, / jer divijač ne odnesu?; On divije drži stvari, / za poštenje ta ne mari,; Izdat, ukrast sveto preže, / nà Latine mnogo reže.; Od nauka nejma slova, / oće dio noćnjeg lova. / Ne zna naprav' ni krstiti, - / neka pođe on brstiti".

46 "Od nji zloća kako vruci, / lupeština svej ù ruci.; U čem gora bi Šodoma? / Ne odmiči, budi doma. / Nut, njijove zakonoše / jesu kako torbonoše: / ne imade rič nauka, / već u torbu da se kljuka. / Samo uče: dobro posti, / mal to, tužan, nije dosti. / Kad ukrade što, sagriši, / oće polu, pak odriši.; svakojako k seb' drljači, / prikladan je oštroj drači".

47 "Dobra dila od nji ne ču, / nit prid Bogom ti ne kleču. / Kada ti se dobar kaže, / to njegovo srce laže.; Neviran je, pun privare, / zlo na drugog natovare. / Zaklinje se svakojako, / a sve žive naopako. / Zaklinje se pun zli riči: / prikrsti se, u nj ne tiči!".

48 “Diviji su Turci nuti / ka Čifuti otvrdnuti”.

49 "Izvan posta ne imadu, / i ramazan Turc' imadu”. 
following: "We would rather serve Mohammed / than be subjects of the Pope, / they ramble"50 (ibid.: 143). In spite of this harsh criticism of Eastern Orthodox Christians (in Dalmatia), Grabovac still prays for their conversion:

Do not ask me about that, / but pray to God for them, / to accept them, - / this shall bring forgiveness to you; Virgin Mother help them, / let them come to you, / so that we can see each other there / and rejoice with you. (ibid.: 143-144) $)^{51}$

Grabovac was born in a confessionally mixed community of Vrlika where "inter-confessional life had to be burdened by conflicts and prejudices" (Dukić 2008: 83). He was a friar from Vrlika. However, he only spent his childhood in his native region, he never conducted pastoral service there, and he spent over half of his life in Italy (ibid.: 84). Nevertheless, Grabovac's worldview, according to Davor Dukić "can be interpreted as an expression of life in a border area understood as the fight for bare life" (ibid.: 84-85). ${ }^{52}$

As opposed to Franciscan Andrija Kačić Miošić, ${ }^{53}$ Grabovac does not make a clear distinction between Eastern Orthodox Greeks and Slavs, which is especially visible in the first part of the book. Greeks adhering to the Byzantine rite (Bogović 1982: 105) in Dalmatia of the eighteenth century were few, and they attempted to merge their religious interests with Eastern Orthodox Morlachs (ibid.). Although in meagre numbers, as more educated and richer than other Eastern Orthodox Christians in Dalmatia, Greeks could significantly influence the development of religious events in the province, as well as the Eastern Orthodox Morlachs and their clergy (ibid.: 101). Therefore, it cannot be completely rejected that such collaboration could have inspired Grabovac for equally (negative) evaluation in the first part of the book.

Grabovac's anti-Eastern Orthodox verses are primarily intended for the Catholic populace, and are, as Dukić points out, of twofold provenance: "on the one hand they come from the written, elite culture, and on the other, they are already the property of its assumed audience" (Dukić 2008: 82). Considering that certain parts in Grabovac's poem (most of those singled out above) feign immediate life experience, i.e., contact with Eastern Orthodox Christians, their negative evaluation could be better explained "as orally

\footnotetext{
50 "Muameda pri dvoriti / neg podložan biti papi, / druge riči kolda klapi".

51 "Ne pitaj me ti od toga, / veće za nje moli Boga, / da jih bude primit k sebi, - / oproštenje biće tebi.; Bogorodna, daj pomoći, / neka budu k tebi doći, / da s' ujedno tu vidimo / i s tobom se veselimo".

52 That Grabovac's confessional exclusivity was not the only, and probably not the dominant attitude among the Franciscans and the Catholics on the Dalmatian border in the 17th and 18th centuries is illustrated by Davor Dukić with a comparison with the annals of Franciscans from Makarska (Pavao Šilobadović, Nikola Gojak, Petar Antulović) who were, in time and space, closer to the work of Grabovac. In some of them, such as the one by Petar Antulović, Davor Dukić detects sympathy for the persecuted Eastern Orthodox Christians (Dukić 2008: 83).

${ }^{53}$ Friendly attitude toward Eastern Orthodox Slavs (and hostile toward the Greeks) can particularly be detected in Kačić in the prose section at the end of poem no. 45 in the second edition of Razgovvor ugodni [A Pleasant Conversation] (1759). This is where he specifically stresses that he has no intention to insult slovinski rišćani (Slavic Christians) (Kačić 1942: 348).
} 
transmitted prejudices about neighbours-people of other religions" (ibid.) than as "bringing down the axiologemes from the written church propaganda among the people" (ibid.).

Still, Grabovac's poem contains verses where he mentions Arianism, Photius and some of his objections to the Western Church, Valentine, and Constantinople as "poisonous people" 54 (Grabovac 1951: 144) and "the nest of all evil"55 (ibid.) which God has punished by the Turkish invasion. These elements are still mostly part of the theological, and problems of ecclesiastical history, and as such are closer to what Dukić stresses here as written, elite culture (here primarily referring to Greek Orthodoxy, of course). Grabovac pejoratively refers to Eastern Orthodox Christians as carijani ${ }^{56}$ and arijani ${ }^{57}$ who are "Imbued with Arianism, / raised in cunning craftiness" 58 (ibid.: 143). Except as the followers of Arius, Grabovac accuses Eastern Orthodox Christians as the legatees of controversial Patriarch Photius: "In them a strain of Arianism, / they follow Photius" 59 (ibid.).

Since he otherwise writes pejoratively on numerous Eastern Orthodox fasts, Grabovac gives a short overview of the issues of Saturday fasting which was existent at the time of the Constantinople Patriarch Photius. ${ }^{60}$

Grabovac's analysed poem is perhaps the best example of his confessional exclusivity and intolerance, here primarily toward the Eastern Orthodox Christians, as well as Muslims, Jews and numerous heretics (especially Arians) outside the Catholic Church. In this type of religious exclusivity, Josip Grbavac recognised echoes of counter-reformation ideology (he particularly stresses intolerance toward the Turks and Greeks, which he principally finds in Grabovac's Cvit razgovora) (Grbavac 1986: 129). Following the same argument,

\footnotetext{
54 "svit otrova".

55 "gnizdo od svi zala".

${ }^{56}$ Emperor's followers.

${ }^{57}$ Arians, follower of Arius.

58 "s arijanstvom zadojeni, / s lukavštinom odgojeni".

59 "U nji žica arijana, / slide nauk focijana".

60 The topic was more extensively covered by a Slavonian Jesuit, Antun Kanižlić, in his expansive polemic debate on ecclesiastical history and theology titled Kamen pravi smutnje velike (The block we stumble over a lot) (Osijek, 1780) where he very negatively evaluates Greek Orthodoxy, and especially Patriarch Photius. Kanižlić explained these issues as the second revilement - Western Christians fast every Saturday. In his work, Kanižlić attempts to explain the difference between the Catholics and Eastern Orthodox Christians (Greeks) as simply as possible - all the faithful fasted on Wednesdays, Fridays and Saturdays in the beginning, however Eastern Orthodox Christians abandoned fasting on Saturdays (except on Saturday before Easter), while Western Christians kept this fast in memory of Christ's funeral (just like the Eastern Orthodox Christians did on Saturday before Easter). Kanižlić finds the reason why Eastern Orthodox Christians (Greeks) abandoned Saturday fasting in their reaction to some unnamed heretics, who, to the revilement of the Jewish God (Kanižlić 1780: 203) fast on Saturdays. The Roman Church, Kanižlić clarifies, was not defiled by such delusions, and has kept the Saturday fast as preached by the apostles (ibid.: 204). For Kanižlić's polemic debate on ecclesiastical history and theology titled Kamen pravi smutnje velike see: Šutalo 2015; 2016. Grabovac also harshly criticizes Eastern Orthodox Christians for avoiding Saturday fasting - "Grom da bije iz nebesa, / u subotu išće mesa" [Thunder should strike from the heavens, / as they ask for meat on Saturday] (Grabovac 1951: 143-144).
} 
Dunja Fališevac explains Grabovac's religious intolerance recognising in it traces of "more radical Catholic and theological and confessional attitudes of the Trident Council" (Fališevac 1998: 51).

In the second part of Cvit razgovora Grabovac describes events from Adam to the Flood, those related to the life of Jesus (octosyllabic poem titled Od porodenja Isukrstova, Zabiliženje događaji ì vrime godina Isukrstovi [From the birth of Jesus, Events recorded in the years of Jesus]) and the time following the resurrection (Posli uskrsnutja Isukrstova razlike stvari koje biše [After the resurrection of Jesus, differences in relation to how things were]), where he chronologically lists events he deems important for the community. Thus he writes about the origin and settlement of the peoples, the history of Dalmatia, important individuals, of whom some are strongly positively presented (primarily Christian heroes who fought the Turks), while some are still negatively presented (Turkish emperors, traitors, heretics, infidels etc.), of important events, wars, where conflicts with the Ottoman empire get a central position, as well as earthquakes, floods, eclipses of the Sun in the period from the 5th century until 1738.

In the paragraph titled Posli uskrsnutja Isukrstova razlike stvari koje biše [After the resurrection of Jesus, differences in relation to how things were] (Grabovac 1951: 185-190) Grabovac gives an overview of the fall of Constantinople in 1453. Grabovac interprets the conquest of Constantinople in line with the prevailing controversistic theology ${ }^{61}$ and with the teachings of cardinal Bellarmin who recognized in the fall of Constantinople (which happened on Whitsunday) God's punishment exerted on Orthodox Greeks for, as Grabovac states, defying the Holy Ghost (Filioque).

In the first part of Cvit razgovora (where religious themes are dominant) we can detect the author's confessional exclusivity and intolerance toward Eastern Orthodox Greeks, as well as toward rkaći. In the second part of the book, which deals with secular topics, Grabovac is much more specific, since his accusations are usually oriented toward individuals, often mentioned by full name. Thus different Slavic brothers (Serbs and Bulgarians) are differently evaluated. Grabovac gives the example of the Battle of Kosovo which took place in 1383 where "Knyaz Despotović Lazo and Miloš Kobilić of Serbia"62 (ibid.: 260) were killed because of infidelity of Vuk Branković and Marko Kraljević, favourably disposed toward Emperor Murat (ibid.). For example, Grabovac writes the following of Marko Kraljević: "Marko Kraljević was from Bulgaria, no book says that he was a hero,

${ }^{61}$ Croatian controversistic theology in the 18th century is mainly directed toward Eastern Orthodox Christians, and its main representatives were Jesuits and Franciscans. For details see: Fuček 2003.

62 "Od Šervije knez Despotović Lazo i Miloš Kobilić". 
instead, they claim that he never adhered to any laws [...]"63 (ibid.: 261), while Miloš Kobilić was a "diligent, good, honest hero"64 (ibid.).

Events that he evokes are, therefore, not related only to the history of the church, but he also describes events from the heroic past. Memory of the heroic past, of great and famous people, is one of the basic strategies of constituting memory. Such events function as historical reference points which strengthen a positive self-image and are coordinated with the aims of certain actions, and what does not fit the image gets forgotten (cf. A. Assmann 2011: 75-76). Using the memory of the heroic past, Grabovac additionally strengthens the identity of the Catholic community by connecting it with heroic, anti-Turkish history (i.e. the history of the faithful).

The Christian-Turkish conflicts are the basic theme of the second part of Cvit razgovora and anti-Islamic attitude is dominant in Grabovac's book. However, when it comes to the Venetian-Turkish wars, ${ }^{65}$ Grabovac does not deal in detail with this particular theme. As Davor Dukić noticed analysing the reflections of the Venetian-Turkish wars of the 17th and 18th century in Croatian literature, Grabovac mentions them by name, he provides short information about them (the beginnings, ends and outcomes or, sometimes, particularly important battles), but "individual parts of Cvit razgovora are not devoted to the wars; historical content is largely built around the major historical personalities, dynasties, peoples and regions" (Dukić 2003: 146). Grabovac writes on the Candian War (the War of Candia), the Morean War (the War of Vienna) and the Second Morean War (Grabovac refers to it as the Third War or a Minor One) by referring to the leading local Christian warriors (serdars and chieftains of Kotor, Šibenik, Kašteli, Klis, Omiš, Makarska, Drniš, Poljica, Vrlika, Sinj, Vrgorac...) (Grabovac 1951: 201-205). In his catalogue of the local warriors he mentions names and gives some brief information on the circumstances of death of each one, but he does not provide information on the political background and the larger historical context.

Grabovac is concerned with the recent past in his local area and the events he describes are those that are important to his intended recipients. Global political events are not of great importance to the message he wants to send. Instead, he focuses on local heroes and places because those themes are close to his recipients and can be used as identitybuilding narratives. As Dukić noticed, "Grabovac always depicted the individual wartime events in decasyllabic verses, and [always connected] those events ... with the newly acquired regions" (Dukić 2003: 146). Decasyllabic verses are a common way of singing (and even thinking) for Grabovac's recipients and events put in the form of verse are more easily remembered and have a higher memory-potential than those in prose form.

63 "Marko Kraljević bi od Bulgarije, mali nijedne knjige ne govore, da je junak bio, nego da nijednog zakona nije držao [...]".

64 "vridan, dobar, pošten junak".

65 The War of Cyprus (1571-1573), the Candian War (1645-1669), the Morean War (1684-1699) and the Second Morean War (1714-1718). 
As far the War of Cyprus (Grabovac 1951: 218-220) is concerned, Grabovac provides information as to its beginning and end, he highlights the Turkish fraud and infidelity, war strategies such as robbery and enslavement (female slaves), but the focus of the text is on the legendary story of a brave Christian woman who sets fire to a Turkish ship (ibid.: 219). The story contains a number of negatively value-charged attributes related to the Turks (infidels, pagans, damned Mohammedans). By explicitly stating that he leaves aside all other information on the Turkish conquest of the Kingdom of Cyprus, Grabovac shows a conscious selection of events he decides to keep in memory. Selected narratives have strong identity-building potential and Grabovac chooses them to reaffirm the positive self-image of the we-community (the Catholic one).

Ancient heroic past, condensed in symbolic figures to which memory is attached (J. Assmann 2005: 61), is necessarily mythologised, free of the factual past and exists only as "remembrance history". Heroes who Grabovac singles out (for example Novak, Radivoj of Smederova, Miloš Kobilić (Obilić), Marko Kraljević, Relja, Mijat Tomić, Janko Hunjadi of Sibinj, Jure Kastriotić Skenderbeg) thus obtain a mythical aura since mythologisation is a process which secures a place in the collective memory. Marko Kraljević is a case in point that shows how a historical character is transformed into a mythical hero, how historical facts become mythical: "Having once entered folk memory Marko's historical character ceases to be, and his biography is reassembled by the rules of the myth" (Eliade 2007: 57). Eliade continues to show how the so-called folk memory (the one preserved in, for example, traditional epic poems) is oriented toward archetypes, not historical characters, since "the memory of historical events and authentic characters after two or three centuries is changed to be able to enter the mould of archaic mentality which cannot accept the individual, instead only preserving role models" (ibid.: 62). In Grabovac, too, historical characters that are singled out function as role models - some as positive ones which should be taken after, and others as negative examples which should not be followed. Thus Grabovac singles out names of renowned heroes "for remembrance"; among them Kraljević Marko (although he also states that written sources do not confirm his heroism): "In those times there were these loud heroes, namely: Novak, Radivoj, Miloš Kobilić, Marko Kraljević, Relja \&c. and many others, and to tell you about them all I do not have enough space here"66 (Grabovac 1951: 261). As opposed to Kačić Miošić who does not talk at length about Kraljević Marko when mentioning heroes in Razgovor ugodni [A Pleasant Conversation], Grabovac lists him among other renowned heroes giving priority to the image created on the basis of epic poems, and not historical facts. Therefore, Kačić is much more critical than Grabovac (at least when it comes to adhering to the sources), which in Kačić's case means better substantiation of the described events by evidence, by written sources. When Grabovac, along with the names of the renowned heroes, mentions Kraljević Marko (with a note that his heroism is not corroborated in books), he takes into

66 "U ova vrimena biše ovi glasni junaci, to jest: Novak, Radivoj, Miloš Kobilić, Marko Kraljević, Relja \&c. i ostali mnogi drugi, à za reć vam ista, ovdi nemam gdi staviti mista”. 
account the perspective of the intended recipients who "know" Marko as a hero from epic poems.

In the short paragraph titled Od izoda kuće Despotovića [The lineage of the house of Despotović] (ibid.: 262) Grabovac clarifies that Despotovići (Brankovići) were "bans from the noble place of Smiderova, knyazes of Serbia, rulers of Bulgaria"67 (ibid.). He reminds the readers that "poor knyaz Lazarus as an infidel"68 (ibid.) died on the battlefield in Kosovo, however, as opposed to him Jure Despotović (despot Đurađ Branković) only "carries a Christian name, while acting on behalf of the Turks" ${ }^{69}$ (ibid.). Grabovac is extremely negative about this despot writing a value-charged description: he is "a cursed exterminator of Christianity"70 (ibid.) and a source of all evil (ibid.) because he collaborates with Emperor Murat, and as a token of his fidelity he gave him two of his sons and his daughter Milica. The author harshly condemns such betrayal by Jure Despotović:

Ever since he became a Christian, no Christian ever did greater evil to Christianity, or can do greater evil than Đuro Despotović of Bulgaria did; he is sly. He would hurt Christians; every heart curses him. (ibid.: 268) ${ }^{71}$

In the second part of the book Grabovac briefly writes about rkaći as thugs searching for profit, but he also connects them to a concrete event. Namely, two of them attacked duke Janko Hunjadi of Sibinj with the intention to rob him. They found a golden cross around his neck and had a fight over it, so Janko managed to escape. (ibid.: 238). Another Vlach, the peasant ${ }^{72}$ (ibid.: 267) intended to rob Janko, but took pity on him in the end and gave him bread and onions to eat because that was the only food he had. Janko also gets into trouble because of the king of Serbia, ${ }^{73}$ "the mean king of Serbia, Greeks and Arians"74 (ibid.: 238) who put him in a dungeon and forced him to take his daughter for his older son Vladislav. Janko later retaliates and goes to Serbia with his army, however the abovementioned king is now again a servile subject of the Hungarian king.

The Ottoman emperor begrudged the king of Serbia for not giving him Janko and for sending an army on Serbia. Upon the appeal of the king of Serbia, Janko comes to his aid and wins against the Turks (ibid.: 238-239). Friar Karlo Eterović explains such differing evaluation of the above-mentioned Slavic individuals as being part of the prevailing oral tradition and folk poems at the time, which conceived of the said persons as traitors of the nation (Eterović 1927: 69). According to Eterović this is adhered to by Grabovac as well, who generally discusses Serbia and its rulers with sympathy. Thus Eterović points out different

67 "bani od plemenita mista Smiderova, knezovi od Servije, principi od Bulgarije".

68 "nevirno siroma knez Lazar".

69 "nosi ime krstjansko, à dilova dilo tursko".

70 "prokleti izkorenitelj krstjanluka".

71 "Odkada je krst postao, krstjanin nije većega zla krstjanluku učinio, niti more učiniti, što učini ovi vrimena Đuro Despotović od Bulgarije; bi prepredeni. On krstjana bi propinjalo, svako ga srce proklinjalo”.

72 Vlah seljanin.

73 "kralj od Rašije".

74 "opaki kralj rašijanski, grk i arijan". 
evaluation of Orthodox Greeks on the one hand and Serbs and Bulgarians on the other, as they are, as Slavic brethren, evaluated positively (ibid.). Some of the examples given above from the second part of Cvit razgovora definitely confirm Eterović's thesis, however, although Grabovac positively evaluates certain Serbian and Bulgarian heroes (always in the context of heroic battles against the Ottomans and without reforming their Eastern Orthodox faith), and writes less negatively about the Eastern Orthodox people (although not even here does he leave out theft, robbery and harsh criticism) than in the first part, we still cannot disregard his pronounced confessional intolerance toward Eastern Orthodoxy in general (especially Greek Orthodoxy, naturally) which culminates in the poem titled Od naravi, ćudi, običaja i prignutja poloviraca aliti starokalendaraca [On nature, temper, customs and accomplishments of the semi-fidels and old-calendar Christians]. Grabovac therefore evaluates Eastern Orthodoxy negatively as a confession, however he singles out and praises renowned Serbian and Bulgarian heroes for their heroic battles against the main religious enemy, the Ottomans. For a more thorough and somewhat more precise (hetero)image of Eastern Orthodox Christian in Grabovac's Cvit razgovora it is therefore necessary to understand these issues in continuity, i.e. in both parts of the book. The praise of the Serbian and Bulgarian heroes who distinguished themselves in the battles against the Turks might therefore, in addition to the dominant anti-Islamic attitude of the author which was clearly "superordinated to Catholic (internal Christian) exclusivity" (Dukić 2008: 75), be explained by the ideology of heroism from oral epic literature, which is incompatible with Christian ideology (ibid.: 70).

Among the heroes singled out by Grabovac, Jure Kastriotić Skenderbeg has an important place: "Jure, from the house of Kastriot, of the last name Skandarbeg, [...] is 63 years old. Died having earned a name for himself, however his heroism was even greater, greater than one can tell”75 (Grabovac 1951: 188). In the prose section titled Od kuće Kastriota [Of the House of Kastriots] (ibid.: 262-270), Grabovac describes events of importance for the activities of Juraj Kastriotić and conflicts between the Turks and Christians. In addition to Skenderbeg, he singles out the heroic actions of Janko Hunjadi who is, together with Jure Kastriotić Skenderbeg, positively evaluated: "From the beginning of the world, there has been no fiercer sabre than the one of Jura Skenderbeg from Arabia and Duke Janko Unijade of Sibinj." (ibid.: 268); "Janko's heroism, praise and gratitude a tongue cannot tell and a pen cannot write: he was a wolf to the Turks."76 (ibid.: 239). In addition to historical information, when it comes to Duke Janko, Grabovac draws information from the oral tradition (belief legends), as well. Those elements can be recognized in the description of Janko's escape after the Second Battle of Kosovo which was mentioned above. Grabovac

\footnotetext{
75 “Jure, kućom Kastriot, à priimenkom Skandarbeg, [...] Živi godina 63. Ostavi svoje veliko ime, mà junaštvo još bi veće, što se izreć ne more”.

76 "Odkada je svit postao, nije bilo žešće ćorde, što je bila Jure Skandarbega od Arbanije i vojvode Janka Unijade od Sibinja” (ibid.: 268); “Jankovo junaštvo, slave ni fale jezik ne more izreći ni pero izpisati: bi turski vuk" (ibid.: 239).
} 
gives two versions of the traditional story of the escape. In one Janko is met by rkaći and robbed by them, but manages to escape thanks to the holy cross:

Janko ran for three days off the beaten track and managed to set himself free. Even his horse died, he fell into the hands of two thugs who were rkaći, desiring profit. They took all of his clothes off and found a golden cross on his chest, had a fight over it, which one would take it. At that point, as Janko watched them fight, he managed to obtain a sabre and strike one, while the other one ran away. There, the holy cross set him free. On the fifth day of his escape he met a peasant. Being greedy, he started hovering over Janko. Seeing that Janko began to pray and pray for mercy with nice words, and gave the peasant a bit of bread as he was dying of hunger. After this and after those words the peasant was appeased and took him to his home and gave him bread and onions, treating him thus, as he had nothing else. ${ }^{77}$ (ibid.: 238)

In the second variant Grabovac uses a more neutral expression for thugs, calling them "two men evil and sinister,"78 whereas the peasant becomes a Vlach (ibid.: 267).

Grabovac draws from the oral tradition (belief legends) as a reference point when he describes the death of King Matijašs ${ }^{79}$ or the episode from the life of Emperor Bayezid and his captivity at the court of Tamerlan, "the king of great Tartaria"80 (ibid.: 260). ${ }^{81}$ When he writes about the genesis of the nation in the section titled Od izoda naroda [Od Škandinavije] [On the settlement of nations [From Scandinavia]], Grabovac gives a variant of the traditional ancestral story of the settlement of the lands which, like the confirmed historical facts, has the power of identity since it secures the relationship with the ancient past, i.e. with the events which acquire mythical reputation.

Heir to the first king of Slavonia, his brother's son by the name of Selimiro conquered Albania and proclaimed himself the king of Dalmatia. Three brothers of Selimir stayed in Slavonija: Leko, Zeko i Rušo, three beautiful noblemen, and I do not know which

77 “Janko biža izvan puta zà tri dni i oslobodi se. Eto pod njim konj crče, pak upade ù ruke dvaju lupeža rkaća, željni za dobiti. Janka svega svukoše i na prsi mu jedan križ nađoše od zlata, tu se o nj zavadiše, koji će ga imati. U to vrijeme Janko gleda, gdi se oni kolju; dobavi se jednoga ćorde pak jednog udri, à drugi uteče. Eto ga križ s. oslobodi. Peti dan bižeći namiri se na jednoga seljanina. Lakom za dobiti obleti Janka. To vidjevši Janko sta moliti i s lipi ričima milosrđe prositi, da mu dade malo krua, zašto od gladi umiraše. S tizim načinom i na te se riči seljanin prignu pak ga povede ù svoju kućicu ter mu dade krua i luka, s tim ga počasti, jer ne imade drugo."

78 "dva čovika zla i opaka".

79 "It is said that on the same day when his soul died, all who were like lions imprisoned in Vienna and Budapest died that second - that is what was said \&tc." (Grabovac 1951: 242).

80 "kralja od Tartarije mnogo moguća".

81 "He went against Tabarlan, King of great Tartaria and when the armies met, they fought a long time and at some point the Turks turned around. Emperor Bayazet ran away, while his horse was pierced by an arrow; running thus the horse fell down on top of the Emperor, this is when the Tatars came running and caught Bayazet alive. They brought him to King Tabarlan. And what did Tabarlan do to him then? He weaved a tree-top from iron and put him in it, tying his hands backwards. When Tabarlan would eat he would throw Bayazet and the dog crumbs and bones, so that Bayazet would have to fight for food with the dog. And Miljava, daughter of Duke Lazar Despotović of Serbia, the wife of Emperor Bayazet; as I said, when king Tabarlan would eat, he would make her serve Emperor Bayazet naked, so after all that wealth Bayzet came down to a life of torture" (ibid.: 260). 
misfortune, or cause, or evil made us lose them. Those from Slavonia ran off, each with his own family and their friends. So they had to run off from Illyria. Leko left and settled in Bohemia, Zeko left and settled in Poland, and Rušo settled in Moscow. ${ }^{82}$ (ibid.: 193)

Belief legends which Grabovac inserts into his chronicle of important events already exist in the imagery of his intended recipients, they are the possession of the community. They have been validated by tradition and as such can function as reference points of memory.

Memory of heroism which has an important role in the construction of community identity is also secured by the octosyllabic poem titled Od naravi i cudi rvacke [On the Croatian nature and character] where Grabovac vests the Croatians with an aura of heroism and secures their remembrance within the framework of the heroic past. Yet he also criticises the position of Croatians and discord among them: "At arms a great hero, / therefore embraced by all kings / and great at his service, / yet they fight among themselves. / When a king wants to conquer someone, he puts Croatians in the front lines, / but when he shares the profit, then they ask: 'Where have you been so far?'"83 (ibid.: 206).

Preserving the memory of renowned people and events is illustrated in the decasyllabic poem titled Rat treći aliti što govore mali: proglasi ga đeneral Anđelo Emo u Sinju na prvi miseca sičnja godine 1715. [The third war or what the people say: proclaimed by general Anđelo Emo in Sinj on 1 January 1715.]. In the manner of folk literature, Grabovac lists the names of the heroes and employs a precise dating of the events: "This happened on 15 August 1715." 84 (ibid.: 229).

Squire Don Ivan Grčić / and Friar Pavle Vučković / and Friar Stipan, Ban's chaplain, / stayed here until the Judgement Day. There were more brethren here / of the order of Saint Francis, good soldiers, / and serdar Bože Vučković: / they defend what cannot be defended anymore. / As well as serdar Jako Tomašević, / they defend the town of Sinj every way they can. / Together with Duke Anton Grabovac, / they defend the faith and the law. / From the infantry there was Duke Culić / as well as Ivan Gulić, / and Grgo Baković, / where are you now Stojo Jaknović! / There were many knights / all of them grey falcons, / whom I did not name here, / because so much time has passed.$^{85}$ (ibid: 226-227)

82 "Prvoga kralja od Šlavonije sinovac, imenom Selimiro, prođe i osvoji Albaniju i zazva se kralj od Dalmacije. U Šlavoniji ostadoše tri Selimirova brata: Leko, Zeko i Rušo, prilipa plemića, mà ne znam, koja bi nesrića, ni uzroka, za koje li zlo dilo pravda jih ktiše zgubiti. Ovi iz Slovinja pobigoše svaki svojom familijom i svojima prijatelji. Tako biše usilovani pobignuti iz Ilirije. Leko ode i naseli Boemiju, à Zeko ode i naseli Poloniju, Rušo naseli Moskovju.".

83 "Nà oružju junak vrli, / svaki kralj ji zato grli / i na službi svojoj drže, / pak s' među se oni prže. / Kad kralj oće da kog srve, tad Rvate meće prve, / a dobitak kad se dili, tad pitaju: 'Gdi ste bili?'”.

84 "Ovo se dogodi na 15. kolovoza godine 1715.".

85 "Kavalijer dom Ivan Grčiću / i fra Pavle starče Vučkoviću / i fra Stipan, kapelan od bana, / tute osta do suđenog dana. / I tu biše više redovnika / svetog Frane, mà dobri vojnika, / i serdaru Vučkoviću Bože: / oni brane, što se više može. / I serdar je Tomašević Jako, / Sinja grada brane svakojako. / Vojvoda je Grabovac Antona, / tere brane vire i zakona. / Od pišaca vojvoda Čuliću / i tu biše Ivane Guliću, / tu je bio Grgo Bakoviću, / gdi si sada, Stojo Jankoviću! / Arambaša biše vitezova / kakonoti sivi sokolova, / kojim ovdi ne stavi imena, / jer je prošlo od tada vrimena". 
Referring to specific historical events and insisting on precision in dating and noting the names of heroes does not exclude mythical reputation of the described heroes. They still, even if put within a (relatively) precise historical framework, obtain mythical character and function as archetypes. Heroes that Grabovac notes in the memory appear as the defenders of Christians, as well as defenders of Croatians, because the two images, confessional Catholic and national, do not exclude one another in Grabovac's perception: "greedy Turks got killed, / the town of Sinj stayed in the Croatian hands"86 (ibid.: 229).

In this poem, Grabovac additionally strengthens the legendary story of the Virgin's liberation of Sinj in popular memory thus invoking the truth mediated through oral tradition. The legend of the Virgin's intervention in the war against the Turks has a unifying force for the Christian community and an important role in the constitution of its identity: it formulates it in relation to the infidel Turks. The Virgin's intervention is proof of the true faith of the Catholics, the defenders of Sinj appear as the defenders of "faith and law," and the Catholic community is additionally strengthened in the image of the protecting Virgin: "The Franciscans / here the Lady with their honesty uphold. / Thank you and your Son: / you destroyed the force and stayed in Sinj" 87 (ibid.).

Legendary stories are present in several places in Cvit razgovora, for example, in the part where Grabovac describes king's Koloman dream (ibid.: 232) in which St. Nicholas, the patron saint of the city of Zadar, forbids king Koloman to attack the city.

Grabovac devotes the greatest amount of space in Cvit razgovora, and especially in its second part, to Turks (Mohammedans) ${ }^{88}$ to whom, much like to the Eastern Orthodox Christians, he writes a poem titled Ponukovanje muamedovcem $u$ verše sastavno [Incentivisation of Mohammedans versified] (ibid.: 256-258). In it he invites the Turks to convert because Jesus suffered for them. Already in the following poem titled Od poturčenika [On converts to Islam] (ibid.: 258-259) he deals with those who converted to Turkish law warning them that they will end up in Hell where Mohammed already is. Anti-Islamic attitude is, as was already explained above, dominant in Grabovac's Cvit razgovora, and it is in this context that Davor Dukić interprets the affirmative attitude toward individual Serbian (Eastern Orthodox) heroes. However, Eastern Orthodox Greeks are evaluated as negatively as the Turks, sometimes even worse than Mohammedans. Such attitude in the second part of Cvit razgovora is perhaps best corroborated by the paragraph titled Serđo, kaluđer reda S. Bažilija, kako učini [Serius, monk of the order of Saint Basilius, what he did] (ibid.: 252-254) where Grabovac writes very pejoratively about monk Sergius, a follower of Nestorian heresy:

He was haughty and prone to dominate in this world, he was not a learned man, but devilish. He renounced and dissented from the holy faith and the law of Jesus, embraced

\footnotetext{
86 "pogiboše pomamljeni Turci, / Sinj grad osta ù hrvaskoj ruci".

87 "Redovnici od svetoga Frane / tute Gospu ù poštenju rane. / Fala tebi i tvojemu Sinu: / silu razbi i osta ù Sinju.".

88 "muamedovci".
} 
the enemy's faith or the wrong faith, that is heresy, Nestorianism, was excommunicated with great revilement and obvious shame. ${ }^{89}$ (ibid.: 252)

This is why Sergius as "a great enemy of all Christianity"90 (ibid.) decided to go to Mohammed and become his advisor to help him conquer the Eastern Empire. In the advice of monk Sergius, the author gives some of the main objections to Islam - "Let them have as many wives as they wish - free the women from the sin of impurity" 91 (ibid.), the ban against drinking wine, the command to go to war and expand the Empire etc. (ibid.: 252-253). However, the main advice by the monk is to be found in the following line: "where the nature draws you, and the easier it is to trust and serve nature, search that"92 (ibid.: 253). With the help of his advice, according to Grabovac, Mohammed managed to attract Jews by telling them that he is the Messiah; to renegade Greeks he promised the return to the Holy church, and to other nations he promised liberation from all kinds of troubles saying that all he desires is joy and merriment in this world (ibid.). It was especially Mohammed, with the assistance of Sergius, who deceived Christians following him "like Eve to the snake"93 (ibid.: 254) since he ordered that Jesus be revered and praised, and decided to be baptised: "And that is when Mohammed gets baptised by Sergio: the devil baptised the Satan"94 (ibid.). Eastern Orthodox Greek Sergius, a monk and Nestorian who closely collaborated with prophet Mohammed, is actually a metonymy of Eastern Orthodox Greek clergy who are represented as markedly cunning and manipulative and prone to collaboration with the main religious enemy of the Christians. Grabovac, therefore, in line with the above discussed dominant anti-Islamic attitude, particularly exposes the collaboration of monk Sergius with Mohammed (who is, in the author's version, in addition to everything else, responsible for drawing up Koran).

\section{CONCLUSION}

Applying identity and memory theory, as closely connected categories, to the analysis of Grabovac's Cvit razgovora provides insights into some of the basic mechanisms whereby memory of community is established in the text, and community identity constructed.

The identity constructed by the author is primarily connected to confessional affiliation (Catholic community) and is realised on the level of the text through the use of strongly value-charged attributes describing, primarily, Eastern Orthodox Christians, as well as all

\footnotetext{
89 “Ovi bijaše nadmen i napregnut zà gospodovati na ovome svitu, bijaše čovik nènaučan ma vragometan. Odvrže se i odpade od svete vire i zakonja Isukrstova, zagrli dušmanluk aliti nepravovirnost, to jest erežiju neštorijana, bi iztiran iz svete crkve s velikom pogrdom i očitom sramotom".

90 "velik neprijatelj svega krstjanluka".

91 "Nek drže žena, koliko mogu, - slobod od bludnosti".

92 “[...] ti dopusti, neka slide, kud narav nateži; i što je lašnje naravi virovati i obsluživati, vidi”.

93 "kakono je Eva k zmiji".

94 "I tada se Muhamed krsti od Šerđa: krsti vrag sotonu".
} 
others who do not belong to the Roman Catholic Church (Turks, Jews, semi-fidels, dissenters from the holy faith, infidels, Calvinists and Lutherans). Grabovac thus negatively evaluates members of all other confessions but the Catholic one, and is especially hard on Eastern Orthodox Christians. Value-charged attributes related to Eastern Orthodox Christians as the confessional Other are pronouncedly negative: for example, renegades, schismatics, semi-fidels, rišćani or rkaći, as well as carijani or arijani. We can take the poem Od naravi, ćudi, običaja i prignutja poloviraca aliti starokalendaraca [On nature, temper, customs and accomplishments of the semi-fidels and old calendar Christians] as a paradigmatic example of the negative evaluation of Eastern Orthodox Christians, where the author amasses negative attributes. Although Grabovac negatively evaluates Eastern Orthodoxy as a confession, he praises eminent Serbian and Bulgarian heroes for their heroism in battles against the common enemy, the Turks. His positive evaluation of individual Eastern Orthodox heroes can be explained through the dominant anti-Islamic attitude expressed in Cvit razgovora.

Grabovac legitimizes the Catholic identity of the we-community which he constitutes through discursive practices of exclusion from and inclusion in the imagined community of the faithful through negative evaluation of the Eastern Orthodox Other. Constructing community identity is closely connected with memory. Namely, Grabovac selects events from religious and secular history, and secures remembrance of the selected events by the community, thus maintaining its identity. Grabovac takes the Holy Writ to which he predominantly refers in the first part of Cvit razgovora as a reference point of memory, while in the second part he gives advantage to secular events (births and deaths of eminent people, wars, conquests, Christianisation, heresy, as well as earthquakes, floods, eclipses etc.) among which events from the heroic past (mostly the Christian-Turkish conflicts from 15th to 18th century) function best as firm points in memory. The Christian-Turkish wars (the War of Cyprus, the Candian War, the Morean (or Vienna) War and the Second Morean War) serve mostly as a historical framework in which Grabovac places Christian and local heroes. Grabovac dedicated a lot of space to Duke Janko Hunjadi and Juraj Kastriotić Skenderbeg, Christian heroes from the Christian-Turkish wars, but he also keeps in memory the names of local warriors from the Christian-Turkish conflicts, serdars and chieftains. Grabovac builds historical content around those historical figures (see Dukić 2003: 146-147). It is precisely the memory of the heroic past that is one of the most successful strategies of the construction of memory and community identity. Ancient heroic past is condensed in symbolic figures to which memory is attached, and heroes who belong to the ancient past which is evoked through mythologisation are kept in cultural memory of the community.

In his representation of the (heroic) past, Grabovac relies on selected historical events, mythologised heroes, legends and belief legends since they, too, mediate information which has cohesive power and which participates in the construction of community identity.

* This text, including the quotations from Grabovac's text and from the critical literature, has been translated by Assistant Professor Tihana Klepač. 


\section{REFERENCES AND SOURCES}

Assmann, Aleida. 2008. "Canon and Archive". In Cultural Memory Studies. An International and Interdisciplinary Handbook. Astrid Erll and Ansgar Nünning, eds. Berlin, New York: Walter de Gruyter, 97-107.

Assmann, Aleida. 2011. Duga senka prošlosti. Kultura sećanja i politika povesti [Long Shadow of the Past]. Beograd: Biblioteka XX. vek, Knjižara Krug.

Assmann, Jan. 2005. Kulturno pamćenje. Pismo, sjećanje i politički identitet u ranim visokim kulturama [Cultural Memory. Writing, Remembrance and Political Imagination in Early Civilization]. Zenica: Vrijeme.

Assmann, Jan. 2006. "Kultura sjećanja” [Culture of Remembrance]. In Kultura pamćenja i historija [Culture of Memory and History]. Maja Brkljačić and Sandra Prlenda, eds. Zagreb: Golden marketingTehnička knjiga, 45-78.

Assmann, Jan. 2008. "Communicative and Cultural Memory". In Cultural Memory Studies:An International and Interdisciplinary Handbook. Astrid Erll and Ansgar Nünning, eds. Berlin, New York: Walter de Gruyter, 109-118.

Bauman, Zygmunt. 2004. Identity. Conversations with Benedetto Vecchi. Cambridge: Polity Press.

den Boer, Pim. 2008. "Loci memoriae. Lieux de mémoir". In Cultural Memory Studies. An International and Interdisciplinary Handbook. Astrid Erll and Ansgar Nünning, eds. Berlin, New York: Walter de Gruyter, 19-25.

Bogović, Mile. 1982. Katolička crkva i pravoslavlje u Dalmaciji za mletačke vladavine [Catholic Church and Orthodoxy in Dalmatia During Venetian Rule]. Zagreb: Kršćanska sadašnjost.

Botica, Stipe. 1990. Filip Grabovac. Zagreb: Zavod za znanost o književnosti.

Dabo, Emina. 2018. "Pučko pjesništvo Ivana Šuljića Iveše i njegova uloga u očuvanju sjećanja zajednice” [Folk Poetry of Ivan Šuljić Iveša and its Role in Preserving Memory of the Community]. In Zbornik radova Šestoga hrvatskoga slavističkoga kongresa održanoga u Vukovaru i Vinkovcima od 10. do 13. rujna 2014. Drugi sv. Stipe Botica et al., ed. Zagreb: Hrvatsko filološko društvo, 657-665. https:// doi.org/10.32728/tab.15.2018.19

Dabo Hunjak, Emina. 2018. “Fenomen pučkoga pjesništva otoka Paga i njegova uloga u zajednici” [Phenomenon of Folk Poetry of the Island of Pag and its Role in the Community]. Tabula 15: 317-331.

Dukić, Davor. 2003. “Contemporary Wars in the Dalmatian Literary Culture of the $17^{\text {th }}$ and $18^{\text {th }}$ Centuries". Narodna umjetnost 40/1: 129-158.

Dukić, Davor. 2008. "Tragovi jednog pograničnog mentaliteta u Grabovčevu Cvitu razgovora" [Traces of a Border Mentality in Grabovac's The Flower of Conversation]. In Tematološki ogledi. Zagreb: Hrvatska Sveučilišna naklada, 65-85.

Eliade, Mircea. 2007. Mit o vječnom povratku [Myth of the Eternal Return]. Zagreb: Naklada Jesenski i Turk.

Eterović, Karlo. 1927. Fra Filip Grabovac, buditelj i mučenik narodne misli u prvoj polovici XVIII vijeka (Njegov život, rad i stradanje) [Fra Filip Grabovac, an Educator and a Martyr of National Thought in the First Half of the 18th Century]. Makarska, Split: Knjižnica "Nove revije".

Fališevac, Dunja. 1998. "Filip Grabovac u kontekstu protureformacije i katoličke obnove" [Filip Grabovac in the Context of the Counter-Reformation and Catholic Revival]. In Znanstveni skup Fra Filip Grabovac u kontekstu hrvatske kulture. Neven Strukan, ed. Vrlika: Poglavarstvo Grada Vrlike, Matica hrvatska Vrlika, Matica hrvatska Sinj, 47-60.

Fuček, Ivan. 2003. "Teologija u XVIII. stoljeću” [Theology in the 18th Century]. In Hrvatska i Europa. kultura, znanost i umjetnost, 3. Barok i prosvjetiteljstvo (XVII-XVIII st.). Ivan Golub, ed. Zagreb: HAZU, AGM, Školska knjiga, 365-377. 
Gillis, John R. 1994. "Memory and Identity. The History of a Relationship". In Commemorations. The Politics of National Identity. John R. Gillis, ed. Princeton: Princeton University Press, 3-24. https:// doi.org/10.1515/9780691186658-003

Grabovac, Filip. 1951. Cvit razgovora naroda i jezika iliričkoga aliti rvackoga [The Flower of Conversation of Illyrian or Croatian people and language]. SPH, 30. Tomo Matić and Josip Badalić, eds. Zagreb: JAZU.

Grbavac, Josip. 1986. Ethische und didaktisch-aufklärerische tendenzen bei Filip Grabovac Cvit razgovora. Slavistische Beiträge, Band 191. München: Verlag Otto Sagner.

Gulin, Valentina. 1998. "Grabovac i Lovrić. Kulturni konteksti 18. stoljeća” [Grabovac and Lovrić. Cultural Contexts of the 18th Century]. In Znanstveni skup Fra Filip Grabovac u kontekstu hrvatske kulture. Neven Strukan, ed. Vrlika: Poglavarstvo Grada Vrlike, Matica hrvatska Vrlika, Matica hrvatska Sinj, $123-138$.

Hall, Stuart. 1996. "Who Needs Identity?". In Questions of Cultural Identity. Stuart Hall and Paul du Gay, eds. London: Sage Publications, 1-18

Jurišić, Karlo. 1983. “Povijest Katoličke crkve u ‘Cvitu’ fra Filipa Grabovca” [History of the Catholic Church in Grabovac's The Flower of Conversation]. Kačić. Zbornik Franjevačke provincije Presvetog otkupitelja, Fra Filip Grabovac i njegovo doba, XV. Split, 201-231.

Kačić Miošić, Andrija. 1942. Razgovor ugodni naroda slovinskoga [A Pleasant Conversation of Slavic Nation]. SPH, 27. Tomo Matić, ed. Zagreb: HAZU.

Kanižlić, Antun. 1780. Kamen pravi smutnye velike illiti pocsetak, i uzrok istiniti rastavlyenya Cerkve Istocsne od Zapadne, po mlogo posctovanomu gospodinu Antunu Kanislichu nyihove Excellencije prisvitloga gospod. biskupa zagrebacskoga Svete Stolice u Poxegi naregyene visce od dvadeset godinah consistorialu nigdascnye pako Druxbe Isusove misniku jurve pokoinomu, za xivota obilato ispisan. S blagodarnostjom pako uzviscene i prisvitle Kralyevske Magyarske komore na svitlo dan. U Osiku kod Ivana Martina Divalta [The Real Stumbling-Block of the Great Discord].

Knapp, Steven. 2006. "Kolektivno pamćenje i stvarna prošlost” [Collective Memory and the Actual Past]. In Kultura pamćenja i historija [Culture of Memory and History]. Maja Brkljačić and Sandra Prlenda, eds. Zagreb: Golden marketing-Tehnička knjiga, 79-109.

Laclau, Ernesto. 1990. New Reflections on the Revolution of Our Time. London, New York: Verso.

Leerssen, Joep. 2007. "Identity/Alterity/Hibridity". In Imagology. The Cultural Construction and Literary Representation of National Characters. Manfred Beller and Joep Leerssen, eds. Amsterdam, New York: Rodopi, 335-342.

Leerssen, Joep and Manfred Beller, eds. 2007. Imagology. The Cultural Construction and Literary Representation of National Characters. Amsterdam, New York: Rodopi.

Marcel, Jean-Christophe and Laurent Mucchielli. 2008. "Maurice Halbwach's mémoire collective". In Cultural Memory Studies. An International and Interdisciplinary Handbook. Astrid Erll and Ansgar Nünning, eds. Berlin, New York: Walter de Gruyter, 141-149.

Martin, James. 2005. "Identity". In Cultural Geography. A Critical Dictionary of Key Concepts. David Atkinson et al., ed. London: I.B. Tauris, 97-103.

Matić, Tomo. 1951. "Život i rad Filipa Grabovca” [Life and Work of Filip Grabovac]. In Filip Grabovac. Cvita razgovora naroda i jezika iliričkoga aliti rvackoga. Tomo Matić, ed. Zagreb: JAZU, 5-18.

Nora, Pierre. 2006. "Između Pamćenja i Historije. Problematika mjestâ" [Between Memory and History. Les Lieux de Mémoire]. In Kultura pamćenja i historija [Culture of Memory and History]. Maja Brkljačić and Sandra Prlenda, eds. Zagreb: Golden marketing-Tehnička knjiga, 23-43.

Rapacka, Joanna. 1995. "Popularne kodifikacije domaće tradicije (iz problema oblikovanja vizije nacionalnog prostora)" [Popular Codifications of the Domestic Tradition (Problems of Shaping the National Space)]. In Dani hvarskog kazališta, Hrvatska književnost 18. st., tematski i žanrovski aspekti. Split: Književni krug, 121-127. 
Rječnik hrvatskoga ili srpskoga jezika. Dio XIV [Dictionary of Croatian or Serbian Language. Part XIV]. 1955. Dragutin Grdenić, Josip Hamm et al., ed. Zagreb: JAZU.

Strukan, Neven, ed. 1998. Znanstveni skup Fra Filip Grabovac u kontekstu hrvatske kulture [Scientific Meeting Fra Filip Grabovac in the Context of Croatian Culture]. Vrlika: Poglavarstvo Grada Vrlike, Matica hrvatska Vrlika, Matica hrvatska Sinj.

Šutalo, Goranka. 2015. “Predodžba Focija (Focijeva shizma) u Kanižlićevoj teološkoj i crkvenohistorijskoj raspravi 'Kamen pravi smutnje velike' (Osijek, 1780.)" [The Image of Focius (Focius's Schism) in Kanižlić's Theological and Historical Polemic Kamen pravi smutnje velike (Osijek; 1780)]. Kroatologija 6/1-2: 190-202.

Šutalo, Goranka. 2016. "Pravoslavni kršćani kao (konfesionalni) drugi u Kanižlićevoj crkvenopovijesnoj i teološkoj raspravi 'Kamen pravi smutnje velike' (Osijek, 1780)" [Orthodox Christians as the (Confessional) Other in Kanižlićs Church History and Theological Treatise Kamen pravi smutnje velike [The Real Stumbling-Block of the Great Discord] (Osijek, 1780)]. Fluminensia 28/2: 121-134.

Tomašić, Josipa. 2015. “Recipijenti pučke književnosti kao polazište za razumijevanje pučke poetike” [Recipients of Popular Literature as a Starting Point for the Understanding of Popular Poetics]. Narodna umjetnost 52/2: 179-194. https://doi.org/10.15176/vol52no209

Tomašić, Josipa. 2016. "Pučka književnost i kulturno pamćenje na primjerima poetike Luke llića Oriovčanina i Andrije Kačića Miošića" [Popular Literature and Cultural Memory on the Examples of Luka Ilić Oriovčanin and Andrije Kačić Miošić]. Fluminensia 28/2: 135-148.

Zečević, Divna. 1978. "Pučki književni fenomen” [Popular Literary Phenomenon]. In Maja Bošković Stulli and Divna Zečević, Povijest hrvatske književnosti, 1. Usmena i pučka književnost. Zagreb: Liber, Mladost, 357-638.

\section{IDENTITET I KULTURNO PAMĆENJE U CVITU RAZGOVORA NARODA I JEZIKA ILIRIČKOGA ALITI RVACKOGA (1747) FILIPA GRABOVCA}

Istraživački je interes usmjeren na tekstnu konstrukciju identiteta i strategije pamćenja u Grabovčevu Cvitu razgovora naroda i jezika iliričkoga aliti rvackoga (1747). Uz pomoć imagološkeanalitičke metode obrađuje se fenomen konstituiranja konfesionalnog (katoličkog) identiteta i (dominantno pravoslavnog) alteriteta. Istraživački je interes stoga fokusiran na tekstnu konstrukciju ili reprezentaciju konfesionalnih identiteta, odnosno alteriteta, $u$ kojoj se mogu uočiti brojni aksiološki obojeni iskazi. Sukladno imagološkoj istraživačkoj paradigmi, istraživanje se, osim na književnopovijesne, oslanja i na kulturnopovijesne spoznaje. Uz imagološku analizu, Grabovčev se tekst promatra i u okviru teorija kulturnoga pamćenja, analiziraju se diskurzivne strategije pamćenja kojima se konstruirani identitet održava, izdvajaju se čvrste referentne točke pamćenja i simboličke figure na koje se pamćenje naslanja.

Ključne riječi: Filip Grabovac, Cvit razgovora, identitet/alteritet, kulturno pamćenje, imagološka analitička metoda 